\title{
The Pinisi Festival as a Tourist Attraction in Bulukumba District of South Sulawesi
}

\author{
Nyoman Siryayasa ${ }^{1 *}$, Andi Jam'an ${ }^{2}$ \\ ${ }^{1}$ Departmet of Convention and Event Management, Makassar Tourism Polytechnic \\ ${ }^{2}$ Depatment of Human Resource Management, Makassar Muhammadiyah University
}

\begin{abstract}
The Pinisi Festival is a national tourism event. The festival is expected to develop the tourism industry in Bulukumba Regency. This study aims to describe and discover the Pinisi Festival's performance and influence as a tourist attraction. This study is qualitative research with a descriptive approach.T he used data collection techniques of this research were observation, in-depth interview, and literature study. The results of this study showed that the Pinisi Festival was held for three days with a variety of activities, i.e. Opening Ceremony, Pinisi Trip from Leppe' Eto Bira, Fishing Contest, GEMARI (Eat Fish Movement) Campaign, Traditional Pinisi Launching Ritual, BergemBira Parade, The Andingingi Kampong Traditional Ritual, Crowbar Burns Ritual, Pinisi Expo, Bulukumba Traditional Dance Performance, Bulukumba Traditional Culinary Festival, and Photography Jamboree. The Pinisi Festival has an impact on increasing the number of both domestic and foreign tourists or increasing of $70 \%$ from the previous few months so that it can be used as a media promotion of the tourism development in Bulukumba.
\end{abstract}

Keywords: Pinisi Festival, tourist attraction, tourism event.

\section{INTRODUCTION}

The Pinisi Festival is a national scale tourism event. This event includes in the 100 Calendar of Event Wonderful Indonesia. The festival held in Bulukumba has been selected through strict curation based on established criteria, i.e. has Creative Value, Commercial Value, and Communication Value, as well as CEO Commitment. These criteria were set in order to make the society get the direct impact of the event, as well as foster a sense of ownership and responsibility to maintain its sustainability [1]. Therefore, this festival is worth visiting.

The festival is held as a means to promote tourism potential and increase tourist visits to South Sulawesi and other cities in Indonesia. The Pinisi Festival is a merry and festive occasion with high historical and cultural values, which then reasonably fit the human needs in recreation. One of the human needs is recreation and refreshment [2]. These attractions are what tourists look for in Bulukumba.

Bulukumba Regency is one of the Level II Regions in South Sulawesi. The capital of this regency is located in the City of Bulukumba. The area of tourism sector in Bulukumba Regency has quite promising prospects, where Bulukumba regency has a substantial capital base, including its artistic and cultural potential and supporting geographical potential. Bulukumba Regency has

\footnotetext{
*Correspondence address:

Nyoman Siryayasa

Email : i.siryayasa@gmail.com

Address : Makassar Muhammadiyah University, J. Sultan Alauddin No.259, Makassar, South Sulawesi 90221
}

many famous tourist attractions, including maritime tourism, nature tourism, historical tourism, culture, religion, and ecotourism.

Bulukumba is a multi-potential district, not only from the agricultural sector and the cultural sector, but also in the tourism sector. Bulukumba regency has promising tourist destinations. The tourism sector in Bulukumba has promising prospects with its substantial capital base, such as its arts, culture, and geographical potential. In addition to the cultural tourism potential, Bulukumba is also famous for its maritime tourism potentials, such as Tanjung Bira Beach area and Lemo-Lemo Beach. They are known for their clean white sand and quite complete facilities.

The development of tourism in Bulukumba does not rely on its natural tourism spots but also its conventions, events, and attractions to invite tourists to visit Bulukumba. According to Law No 10 of 2009, tourist attractions are all things that have a uniqueness, beauty, and value of diversity of natural resources, culture and home-made products that become the destinations of tourist visits. The attraction is what first draws visitors' interest to an area or, in the sense of development, tends to be developed first. Attraction is a tourist destination that presents different characteristics of each region. Regional attractions can be natural phenomena (geography, fauna, and flora) and events that contain cultural values, religion, sportsmanship, and other festivals [3]. Therefore, efforts to manage cultural areas as national heritage need to be done as a source of foreign exchange [4]. 
The Pinisi Festival can be a tourism event to promote tourism objects in Bulukumba. Tourism event is a marketing strategy undertaken by the government to attract the attention of tourists and to introduce tourist destinations. Event tourism is the systematic planning, development and marketing of planned events as tourist attractions, and for their benefits to place marketing, image-making, and development [5]. Therefore, this festival presents various traditional cultures to entertain tourists, especially the people in Bulukumba.

The Pinisi Festival is conducted by the government to increase contribution and add value to the surrounding community. It is also supported by a study, which found that to make museums noticeable by tourists, managers need to create some appropriate marketing strategies to compete in the tourism industry, such as by implementing an atmospheric and event marketing strategy [6]. Besides, the promotion of tourist destinations, culture, and potentials of the area are also some effective strategies to attract tourists.

The Pinisi Festival has been held for ten years. However, this festival has not been included in the top 10 festivals of the tourism ministry. It is because this event does not yet have strong branding. Tourism events can create a favorable image for a destination, expand the traditional tourist season, develop tourist demand more evenly through an area, and attract foreign and domestic visitors [7]. Therefore, the author is interested in studying the attraction of the Pinisi festival for tourists and its influence on the level of tourist attractions that spread in Bulukumba Regency. This study aims to determine the effect of the Pinisi Festival as a tourist attraction on increasing tourist arrivals in Bulukumba Regency.

\section{METHOD}

This research is qualitative research with a descriptive approach, a theory that describes all phenomena, data, and information obtained compared with existing theories so that conclusions can be drawn. This study revealed the implementation of the Pinisi Festival as a tourist attraction in Bulukumba and the efforts that should be made by the local government in managing and the presence of supporting factors, especially those related to increasing the number of visits.

\section{Data Collection}

The data collection technique used in this study was Participation Observation. The author conducted an observation during the Pinisi Festival. The author follows all the series of activities from the opening to the closing. The series of activities lasted for three days, from $12^{\text {th }}$ to $15^{\text {th }}$ September 2019 . During the observation, the author involved actively observing the Pinisi Festival activities to obtain more accurate data.

After collecting the observation data, the author then conducted an in-depth interview with the informants. The number of informants in this research is three people, i.e. the Head of the Tourism Office of the Bulukumba Regency as the person responsible for the implementation of the Festival, the Secretary of the Tourism Office of the Bulukumba Regency and the Chair of the Organizer of the Festival of Pinisi in the Bulukumba Regency. In addition, author conducted a literature study for data collection.

The data analysis process is carried out in three stages, namely reduction, display, and conclusion/verification of data. Data that has been collected will be reduced and simplified so that data that is not needed will be sorted. After that, the data is presented by displaying models, typologies, matrices, and tables so that the entire data and its detailed parts can be mapped. Then we verified the data findings to the informant. The findings of the first informant will be compared with the second and third informants. Based on the information, the meanings, interpretations, and conclusions are made.

\section{RESULTS AND DISCUSSION}

\section{Potentials of Bulukumba Regency}

Bulukumba is an area located in the southern part of South Sulawesi province. Bulukumba has enchanting highlands, lowlands, coastal areas, and wide-open seas. Also, natural resources and cultural uniqueness are very alluring. Moreover, the expertise of the community in making Pinisi Boat has well-known worldwide. Geographically, Bulukumba is located at coordinates between $5^{\circ} 20$ to $5^{\circ} 40$ South Latitude and $119^{\circ} 50$ to $120^{\circ} 28$ East Longitude. With territorial boundaries including:

- Sinjai Regency to the north side

- Selayar Regency to south side

- Gulf of Bone to the east Side

- Bantaeng Regency to the west side

The majority of people in Bulukumba are Muslim. They holds the principle of Mali Siparappe Talla Sipahua, which is an illustration of the inner attitude of the Bulukumba people in carrying out the mandate to reach unity and safety of the world and the hereafter [9]. 
Administratively, Bulukumbaregency is divided into ten districts, consisting of 27 subdistricts, 109 villages, and 400,990 people. The area of Bulukumba reaches $11,554.67 \mathrm{~km}^{2}$, with a coastline of approximately $128 \mathrm{~km}$ [10].

It is undeniable that Bulukumba is one of those districts with famous tourist attractions for domestic and foreign tourists. Bulukumba is known for its motto Sailing Bulukumba. It has an enchanting nature and is very prospective for tourism. Besides, there are cultural tourism, religious tourism, and technology tourism. These potentials are a huge asset and will contribute to increasing the economic turnaround and increasing regional income (PAD) from the tourism sector. Some of the top tourist attractions in Bulukumba that are worth visiting by both domestic and foreign tourists, such as:

\section{Bira Beach}

It is located in Bonto Bahari District, $\pm 42 \mathrm{~km}$ to the east of the capital city of Bulukumba. Bira Beach is famous for its beautiful white sand and clear water that is wonderful for swimming and sunbathing (Fig. 1). Tourists can also enjoy the perfect view of sunrise and sunset.

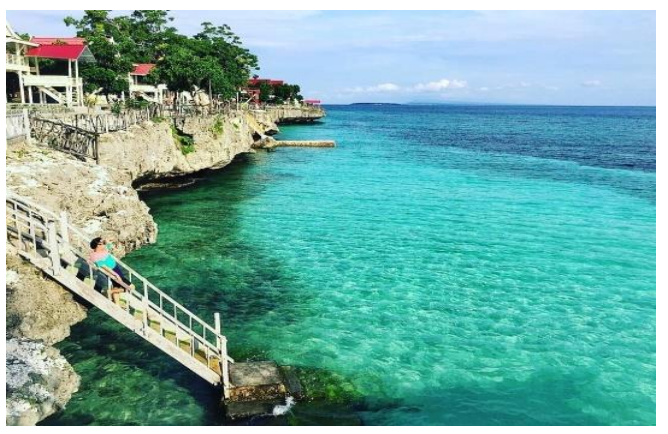

Figure 1. Bira Beach

(Source: bulukumbakab.go.id)

Lemo-Lemo Beach

This 508 hectares beach is located $\pm 7 \mathrm{~km}$ from Tanaberu (Fig. 2). It also has a fascinating panorama compared to other beaches in Bulukumba.

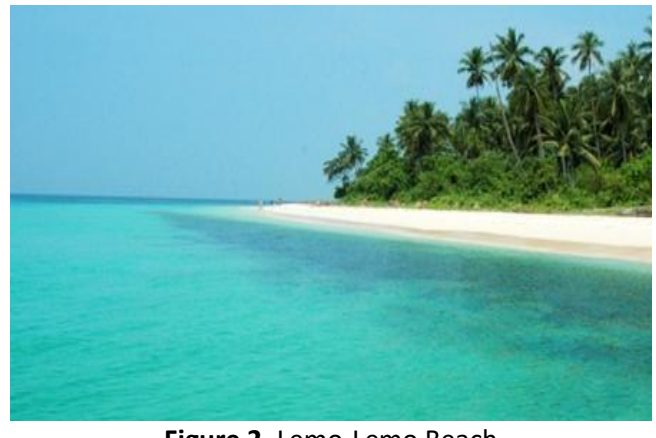

Figure 2. Lemo-Lemo Beach

(Source: bulukumbakab.go.id)

\section{Samboang Beach}

It is located in Eka Tiro village, Bonto Tiro District (Fig. 3). It has panorama beauty, curvy and sloppy shoreline, and enchanting coral refs.

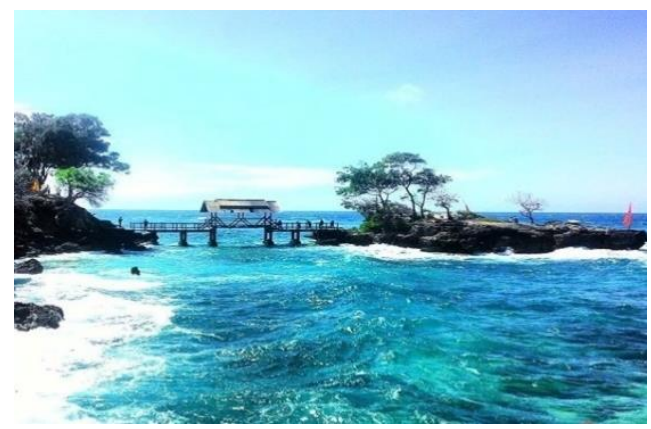

Figure 3. Samboang Beach

(Source: bulukumbakab.go.id)

Indigenous Region of Ammatoa

It is located in Tanah Towa village of Kajang District, $\pm 56 \mathrm{~km}$ from the City of Bulukumba. The people still hold the message of the ancestors called Passangnga Ri Kajang and its cultural and natural authenticity. This area is untouched by technology, even just electricity. This village also upholds the ethics of politeness (Fig. 4).

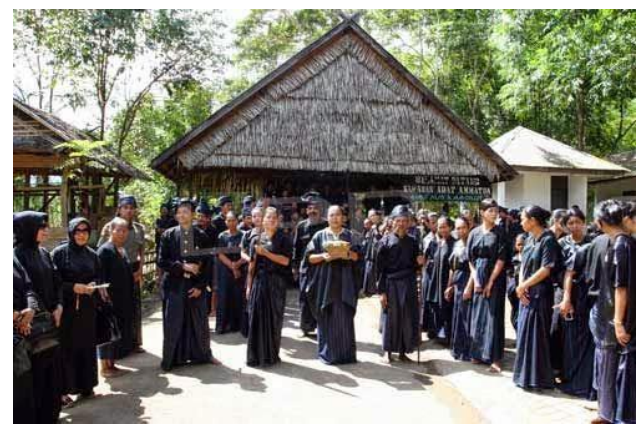

Figure 4. Tanah Toa People (Source: bulukumbakab.go.id)

\section{Pinisi Boat Making Area}

It is located in Tanaberu, $\pm 24 \mathrm{~km}$ from the city of Bulukumba. Tanaberu is a symbol of Bulukumba regency that is called Bumi Panrita Lopi. In Tanaberu, tourists can see firsthand the process of making Pinisi ships (Fig. 5).

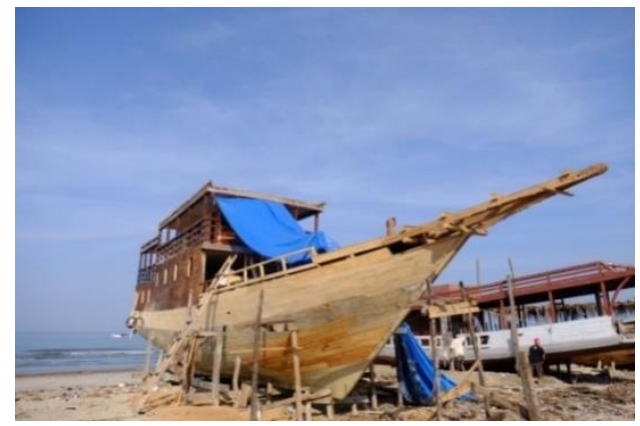

Figure 5. Process of making Pinisi (Source: bulukumbakab.go.id) 


\section{Cliffs of Appalarang}

It is located in Are village of Bonto Bahari District. It has beautiful cliffs with clear seawater, enjoyable an atmosphere, and wonderful coral reefs (Fig. 6). In this location, tourists can do snorkeling and Cliff jumping activities.

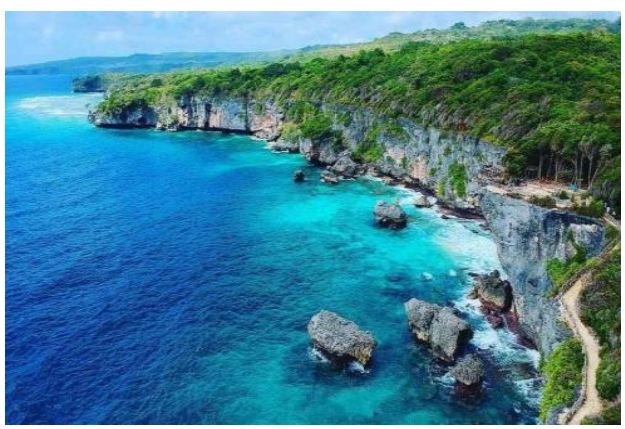

Figure 6. Appalarang

(Source: bulukumbakab.go.id)

\section{The Pinisi Festival}

Bulukumba, which is one of the main tourist destinations in South Sulawesi, has various tourist objects. It includes Bira Beach with its clear white sand, the indigenous people of Ammatoa in Kajang with their local wisdom, and craftsmen of traditional Pinisi boat that has been known across the globe [11]. The resilience of the Bugis Makassar sailors is also very well known throughout the archipelago and worldwide.

In 2010, the Tourism Department of Bulukumba regency has started to held the Pinisi Festival and made it as an annual tourism agenda as a means to enliven maritime traditions in Indonesia, especially in Bulukumba. The aims and objectives of the Pinisi Festival are as follows:

a. Empowering local potentials in supporting the government's Twenty Million Tourist Visit program to Indonesia.

b. Preserve and introduce cultural diversity in Bulukumba to the world and to strengthen Bulukumba as one of the main tourist destinations in Eastern Indonesia.

c. Exploring and developing regional culture as a means to enrich national cultural treasures.

d. Educate young people to recognize and appreciate their culture and customs.

Profile and Activities of the Pinisi Festival as a Tourist Attraction

Based on the result of interviews and direct observations about profile and activities of the Pinisi Festival in which the activities lasted for three days, the series of activities are as follows:

Opening Ceremony

It was held at the Leppe' Pier, with original Pinisi Boat panorama. The Pinisi Boat has two masts with seven sails, followed by several other sailboats that will take part in the Leppe' to Bira Trip. The Opening Ceremony was opened by the Governor of South Sulawesi, who was accompanied by the Regent of Bulukumba who also gave a speech. The ceremony was opened by the Gendang/Ganrang beats by the South Sulawesi Governor and other officials, which also starts the Leppe' to Bira Trip.

\section{Pinisi Trip from Leppe'toBira}

This activity was joined by Pinisi boats and other sailboats from Bulukumba to Bira $( \pm 20$ miles away). Pinisi trip from Leppeto Bira was released directly by the Governor of South Sulawesi.

\section{Fishing Contest}

The fishing competition was joined by participants of the Pinisi trip from Leppe'E to Tanjung Bira Beach. Each team consists of seven participants with fishing areas across the Leppe Bira (Flores Sea) track.

\section{GEMARI (Eat Fish Movement) Campaign}

This activity is a moral movement motivating people to consume fish regularly in the amount required for human health. This event involves tourists in the Pinisi Festival to cook the fish caught by the fishermen of the Trip Leppe, which were provided by the committee. Then they eat the cooked fish together.

\section{The Traditional Pinisi Launching Ritual}

In this activity, there are several performing rituals, as follows.

- The Appasili ceremony is a ward off misfortune ritual held in the morning before the Pinisi boat launching.

- The Barasanji is a reading prayer ritual before the Pinisi boat launching.

- The Ammossi ceremony is the highlight of the Pinisi boat launch ritual. This ceremony is a finding center of the boat ritual as a symbol of the birth of Pinisi boat into the world by traditionally pulling the boat into the sea.

\section{BergemBira Parade}

This activity shows cultural parade/carnival of participants from ten districts in Bulukumba. Each district showed unique characteristics of each region.

\section{Andingingi Kampong Traditional Ritual}

It is a Kajang Customary Community Indigenous Ritual as a manifestation of the closeness of the Kajang people to nature. The activity is a replication of the original traditional 
ritual adingingi lino, which in its performance, prohibited from being documented in any form.

\section{Crowbar Burns Ritual}

This custom is known as Attunu Panroli, which is one way to uphold justice. The ritual is carried out by the crowbar that has been burned and smoldered, held by the accused. If his hands are blistered, then he is the culprit. However, if his hand is fine, then he is not the culprit and free from the accusation.

However, at this festival, it does not intend to uphold justice. It is only as one of the cultural attractions that are performed together with the Andangingi Kampong, which shows the shaman's magic. They do not feel anything while holding the crowbar.

\section{Pinisi Expo}

This exhibition was held around Bira Beach. The expo shows the potential of the region, agricultural products, local culinary and creative industries in Bulukumba.

\section{Bulukumba Traditional Dance}

Bulukumba traditional dances were performed by dancers from the delegates of ten districts in Bulukumba Regency. It showed in Figure 7.

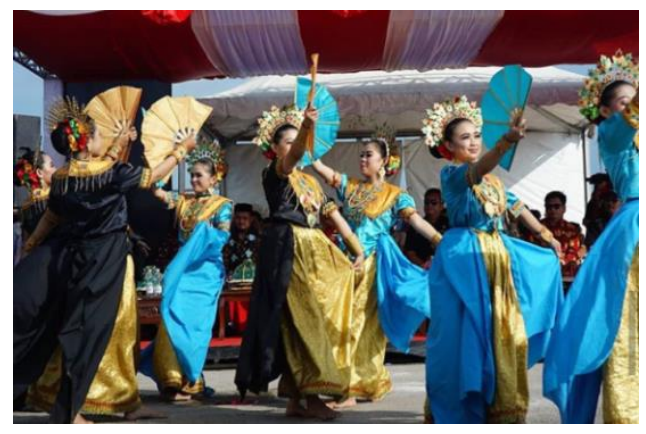

Figure 7. Traditional Dance

(Source: bulukumbakab.go.id)

\section{Photography Jamboree}

It is a photography competition that captures objects and tourist attractions in Bulukumba, both in the form of landscape and human interest photos. The photography Jamboree participants capture every series of Pinisi Festival events.

\section{Night Entertainment}

Every night, in three days of the festival, the committee and the Event Organizer presented national and local artists to entertain the visitors, including traditional dance and Bulukumba traditional music Turiolo performed by artists under the Tourism Department of Bulukumba.

\section{The Development of Pinisi Festival as a Tourist Attraction}

Even though the Pinisi Festival is an annual event, but it won't immediately be able to increase tourist visits significantly. It is necessary to analyze several factors that can influence and obtain support from all components, such as government policy, transportation facilities readiness, availability of convention centers, hotels, restaurants, attractions, association support, and human resources.

Another important consideration that strengthens the potential of Bulukumba as one of the tourism cities is the existence of its strategic location. Developing a tourist attraction in a tourist destination cannot release the product components of attractions, accessibility, or facilities because these three components can make the attraction of a tourist attraction [12]. Accessibility requirements consist of access to information where facilities must be easy to find and easily reachable, must have access to road conditions that can be traversed, and get to the tourist attractions, and there must be an end of a trip [13]. Therefore, facilities and access to several attractions are very crucial to increase the number of tourist visits.

Pinisi Festival impacts are in the accommodation sector, restaurants, the renting hall service, the service rental industry, etc. Events have effects to attract tourists, help in improving infrastructure and capacity of tourism destinations, foster a positive destination image, and contribute to marketing public places. It also encourages better places to live, work and invest, and enliven the attractions or areas $[13,15]$. Indirect impacts are on the industrial sectors that are not directly needed when the tourism event (Pinisi Festival) takes place, such as the plantation industry, printing industry, advertising, etc. Other impacts are on the handicraft industry (making souvenirs), small stalls, etc. In addition to the multiplier effect, tourism event has several advantages and benefits for the development of several sectors. The benefits are:

1) Improve the tourism destination image

2) The tourists' impression that the destination is safe

3) Increase the number of foreign tourists and vice versa

4) Occupy related services (transportation, accommodation, restaurant exhibition equipment etc.)

5) Introduce Indonesia with all its potential to the world. 
Among many advantages and benefits of tourism events, the tourism industry in the future can surpass other industries as contributors to GDP after the oil and gas sector, the forestry sector, agriculture, etc. Additionally, the Head and the Secretary of Bulukumba Tourism Department mentioned that the Pinisi Festival is a cultural tourism and an annual event by the Bulukumba Government. The visitors are from domestic and foreign tourists who specifically come to watch the Pinisi Festival, which presents the unique potential of cultural and natural tourism in Bulukumba, i.e. Butta Panrita Lopi.

At least 10,000 people, both domestic and foreign tourists, gathered at the event. It resulted in an increase of 70 percent from the previous few months. Attractions are the primary elements of the destination appeal. They are the key motivators for visitation to a destination [14]. It shows that the Pinisi Festival can be an attraction for tourists. The following data illustrate the increasing number of tourists visiting the Bulukumba Regency in the past five years.

Table 1.The number of tourist in the Bulukumba Regency

\begin{tabular}{cccc}
\hline \multirow{2}{*}{ Years } & \multicolumn{2}{c}{ Tourists } & \multirow{2}{*}{ Total } \\
\cline { 2 - 3 } & Foreign & Domestic & \\
\hline 2013 & 3.425 & 115.343 & 118.764 \\
2014 & 4.195 & 137.087 & 141.282 \\
2015 & 3.760 & 156.770 & 160.530 \\
2016 & 3.421 & 158.695 & 162.116 \\
2017 & 3.036 & 186.145 & 189.181 \\
2018 & 3.821 & 200.113 & 203.934 \\
\hline
\end{tabular}

Source: Bulukumba Regency Culture and Tourism Office

The organizers only rely on a very limited budget from Local Government Budget (APBD) and State budget (APBN), so the event does not have a maximum impact on the development of tourism in Bulukumba. The lack of the event caused by the financial issues surely will affect the tourists visit in other events, such as meetings that are usually held either by government agencies, companies, or private parties.

As we know, the tourism industry is one of the leading sectors in a country. Tourism is one of the promising sectors, but only a few cities in Indonesia held national scale tourism events. The implementation of tourism events has a huge multiplier effect. Many employment opportunities are created as the event is held. Events are powerful drivers in tourism and prominent figures in the development and marketing plans of most destinations [15].
However, The Head of Tourism Department of Bulukumba stated that the event has not been effectively carried out. So the effect of the event is not optimal in helping people's economic situation and regional income.

On the other side, publication and promotion of the Pinisi Festival event are carried out nationally through radio, television, newspaper, internet, press conferences, as well as direct invitations to relations and related agencies and promotion through below the line activities (billboards, banners, archways, leaflets etc). These activities were carried out to invite visitors to come and watch the Pinisi Festival.

Furthermore, the Tourism Department distribute tickets with doorprizes (motorcycle, handheld transceiver, and other entertainment prizes), which was drawn on the closing night of the festival. Year to year, the Pinisi Festival still relies on the Local Government Budget (APBD), so the Government of Bulukumba through the Tourism Department builds a partnership with all parties who can support these activities. Therefore, the organizers should pay attention to things that are very important in holding the event, as follows.

1) Profitability; where a location can earns profits or losses in organizing events

2) Promotion of associations; whether a predetermined location can increase credibility and increase membership

3) Novelty; to what extent a location presents a new location for organizing an event

4) Hospitality; to what extent the host and the local community welcoming visitors.

\section{CONCLUSION}

The Pinisi Festival, as a tourist attraction in Bulukumba, has various activities to increase the number of tourist visits, both local and foreign. Pinisi Festival impacts are in the accommodation sector, restaurants, the renting hall service, the service rental industry, etc. The involvement of the Tourism Department as the spearhead at the event will have more policies and authority, which has a crucial component in carrying out an event or festival. As Suggestions, the Tourism Department and the local government as the organizer of the Festival need to enhance cooperation and collaboration with other relevant agencies to gain more supports as a means to hold the festival optimally. It is also expected to improve the strategies that have been set to achieve targets and to attract tourists to visit Bulukumba. 


\section{Acknowledgement}

The researchers would like to thank Mr. Muh. Ali Saleng, SH. MH. as the Head Tourism Department and Mr. H.A. Mattampawali as the Secretary of Tourism Department, and organizers of the Pinisi Festival, as well as the informants in this study.

\section{REFERENCES}

[1] Ministry of Tourism. 2019. Calendar event Wonderful Indonesia. Indonesian Ministry of Tourism. Jakarta.

[2] Attar, M., L. Hakim, and B. Yanuwiadi. 2013. Analisis potensi dan arahan strategi kebijakan pengembangan desa ekowisata di Kecamatan Bumiaji-Kota Batu. Journal of Indonesian Tourism and Development Studies 1(2), 68-78.

[3] Mill, R. C. 2000. Tourism: the international business, $1^{\text {st }}$ Ed. Sastrio, T. B. (transl). PT Raja Grafindo. Jakarta.

[4] Ridwan, M., A. Fatchan, and I K. Astina 2016. Potensi objek wisata Toraja Utara berbasis kearifan lokal sebagai sumber materi geografi pariwisata. Jurnal Pendidikan: Teori, Penelitian, dan Pengembangan 1(1), 1-10.

[5] Higgins, F. 2017. Event tourism and event imposition: a critical case study from Kangaroo Island, South Australia. Journal Tourism Management 64, 73-86.

[6] Putri, N. N., A. T. Haryono, and M. M. Warso. 2016. efektifitas atmospher dan event marketing terhadap keputusan pembelian yang dimediasi oleh minat beli pada konsumen Tembi Rumah Budaya Yogyakarta. Journal of Management 2(2).

[7] Damster, G. and D. Tassiopoulos. 2005. Event management: a professional and development approach, $2^{\text {nd }}$ Ed. Juta Academic. Lansdowne.

[8] Simanjuntak, D. F., A. Fauzi, and A. Irawan. 2018. Pengaruh event pariwisata terhadap keputusan berkunjung (survei pada wisatawan domestik yang berkunjung ke event pariwisata di kabupaten banyuwangi). Jurnal Administrasi Bisnis 61(3), 144-153.

[9] Syarif, E. 2017. Studi fenomenologi makna pasangri kajang dalam pengelolaan hutan masyarakat adat Ammatoa Bulukumba Sulawesi Selatan. PhD Thesis. Postgraduate of Geography Education, State Universiry of Malang. Malang.
[10] Statistic Center. 2019. Bulukumba in Number. Bulukumba Statistic Center. Bulukumba.

[11] Syarif, E., A. Fatchan, I K. Astina. 2019. Tradition of "Pasang Ri-Kajang" in the forests managing in system mores of "Ammatoa" at District Bulukumba South Sulawesi, Indonesia. Mediterranean Journal of Social Sciences 7 (6), 325.

[12] Abdulhaji, S. and I. S. H. Yusuf. 2016 Pengaruh atraksi, aksesibilitas, dan fasilitas terhadap citra objek wisata Danau Tolire Besar di Kota Ternate. Jurnal Penelitian Humano 7(2), 134-148.

[13] Soekadijo, R. G. 2003. Anatomi pariwisata. Gramedia Pustaka Utama. Jakarta.

[14] Getz, D. 2008. Event tourism: definition, evolution and research. Journal Tourism Management 29, 403-428.

[15] Geoffrey I., J. R. Crouch, B. Ritchie. 1999. Tourism, competitiveness, and societal prosperity. Journal of Business Research 44(3), 137-152. 